\title{
(6) OPEN ACCESS \\ EGFR mutation testing in lung cancer: a review of available methods and their use for analysis of tumour tissue and cytology samples
}

\author{
Gillian Ellison, ${ }^{1}$ Guanshan Zhu, ${ }^{2}$ Alexandros Moulis, ${ }^{3}$ Simon Dearden, ${ }^{1}$ \\ Georgina Speake, ${ }^{1}$ Rose McCormack ${ }^{1}$
}

${ }^{1}$ AstraZeneca, Macclesfield, Alderley Park, UK

${ }^{2}$ AstraZeneca R\&D, Shanghai, China

${ }^{3}$ AstraZeneca SA Hellas, Athens, Greece

\section{Correspondence to} Dr Gillian Ellison, AstraZeneca, Alderley Park, Macclesfield, Cheshire SK10 4TG, UK; gillian.ellison@astrazeneca.com

Received 10 September 2012 Revised 19 October 2012 Accepted 22 October 2012 Published Online First 20 November 2012

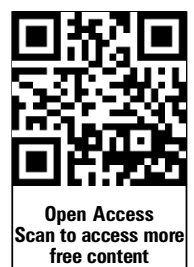

To cite: Ellison G, Zhu G, Moulis $A$, et al. I Clin Pathol 2013;66:79-89.

\section{ABSTRACT}

Aims Activating mutations in the gene encoding epidermal growth factor receptor (EGFR) can confer sensitivity to EGFR tyrosine kinase inhibitors such as gefitinib in patients with advanced non-small-cell lung cancer. Testing for mutations in EGFR is therefore an important step in the treatment-decision pathway. We reviewed reported methods for EGFR mutation testing in patients with lung cancer, initially focusing on studies involving standard tumour tissue samples. We also evaluated data on the use of cytology samples in order to determine their suitability for EGFR mutation analysis. Methods We searched the MEDLINE database for studies reporting on EGFR mutation testing methods in patients with lung cancer.

Results Various methods have been investigated as potential alternatives to the historical standard for EGFR mutation testing, direct DNA sequencing. Many of these are targeted methods that specifically detect the most common EGFR mutations. The development of targeted mutation testing methods and commercially available test kits has enabled sensitive, rapid and robust analysis of clinical samples. The use of screening methods, subsequent to sample micro dissection, has also ensured that identification of more rare, uncommon mutations is now feasible. Cytology samples including fine needle aspirate and pleural effusion can be used successfully to determine EGFR mutation status provided that sensitive testing methods are employed.

Conclusions Several different testing methods offer a more sensitive alternative to direct sequencing for the detection of common EGFR mutations. Evidence published to date suggests cytology samples are viable alternatives for mutation testing when tumour tissue samples are not available.

\section{INTRODUCTION}

Lung cancer is the most frequently diagnosed of all cancers and is responsible for approximately 1.38 million deaths each year worldwide. ${ }^{1}$ Non-small-cell lung cancer (NSCLC) is the most common form of lung cancer and first-line treatment of advanced NSCLC often involves platinum-based combination chemotherapy. ${ }^{2}$ However, for patients with advanced NSCLC harbouring an activating mutation in the tyrosine kinase (TK) domain of the epidermal growth factor receptor (EGFR), targeted treatment is available in the form of the EGFR TK inhibitors (TKIs) gefitinib and erlotinib.

Activating somatic mutations in the EGFR gene conferring sensitivity to EGFR TKIs were first reported in $2004 .^{3-5}$ Since then, the efficacy of first-line gefitinib and erlotinib in patients with EGFR mutation-positive advanced NSCLC has been demonstrated in a number of Phase III trials. ${ }^{6-11}$ In the Iressa Pan-Asia Study, progressionfree survival (PFS) was significantly longer with gefitinib than carboplatin/paclitaxel for patients whose tumours harboured activating EGFR mutations. In patients with wild-type EGFR, carboplatin/paclitaxel was associated with significantly longer PFS than gefitinib. ${ }^{8}$ The conformational change seen in the TK domain of mutated EGFRs increases the activation of the domain and its affinity for ATP (and EGFR TKIs) compared with wild-type EGFR. ${ }^{3}$ The resulting increase in binding of EGFR TKIs produces greater inhibition of the domain and blocking of signal transduction pathways implicated in the proliferation and survival of cancer cells. Gefitinib also improved PFS versus chemotherapy in two Phase III trials performed solely in patients with EGFR mutationpositive advanced NSCLC. ${ }^{6}{ }^{7}$ In addition, in two Phase III erlotinib trials that recruited EGFR mutation-positive patients, PFS was significantly increased with first-line erlotinib relative to chemotherapy. ${ }^{9}{ }^{10}$ As a result of these data, the accurate identification of patients who might benefit from EGFR TKI therapy has become an important step in the treatment-decision pathway for advanced NSCLC. ${ }^{9} 12$

Mutations associated with enhanced sensitivity to EGFR TKIs are found in exons 18-21 of the TK domain of EGFR. ${ }^{34}$ Two types of mutation-short in-frame deletions in exon 19, clustered around the amino-acid residues $747-750$ and a specific exon 21 point mutation (L858R) - have been reported to comprise up to $90 \%$ of all activating EGFR mutations. $^{3} 413$ Other activating mutations include point mutations in exon 18 (including mutations in codon 719) and point mutations and in-frame insertions in exon 20 (including T790M). The prevalence of EGFR mutations differs according to ethnicity; approximately $10-12 \%$ of non-Asian patients with advanced NSCLC harbour these mutations compared with $30-40 \%$ of Asian patients. ${ }^{14-16}$

Historically, the standard for EGFR mutation testing involved direct sequencing of DNA extracted from samples of tumour tissue gathered during biopsy or resection, usually in the form of formalin-fixed paraffin-embedded (FFPE) diagnostic blocks. Direct sequencing, however, has low sensitivity (ie, only detects mutations when sufficient levels of mutant DNA are present), can be complex 
and time-consuming, and is not standardised in terms of laboratory practice. ${ }^{17} 18 \mathrm{~A}$ number of alternative methods for mutation testing have been developed and used over recent years, many with improved sensitivity and turnaround times. Another area of active research has been the evaluation of alternative sources of tumour material. As many patients with lung cancer are not identified until they have advanced disease, the procedures required to obtain a tumour biopsy sample for diagnosis may not always be possible due to co-morbidities or other reasons. Instead, cytology samples can be collected as they are adequate for the diagnosis and staging of the disease, and the procedures used to obtain these samples are generally less invasive than those used to obtain a biopsy sample. In this regard, the use of cytology samples collected for diagnostic purposes or as a result of disease complications (eg, pleural effusion (PLE)) has attracted particular attention. ${ }^{19}$

The first objective of this review was to identify and compare reported methods for EGFR mutation testing in patients with lung cancer. We focused on studies involving samples of biopsied or resected tumour tissue for this purpose because, in comparison with other sources of tumour DNA, such samples have traditionally been considered the standard for mutation testing. Our second objective was to evaluate published data on EGFR mutation testing in cytology samples when used to diagnose lung cancer in an effort to determine whether such specimens are viable alternatives to standard tumour tissue samples.

\section{LITERATURE SEARCH METHODOLOGY}

A MEDLINE database search was performed on 27 April 2012 to identify original study articles reporting on methods for EGFR mutation testing in patients with lung cancer. The following search terms and criteria were used: (mutation detection methods lung (All fields) AND EGFR (Title/Abstract) AND mutation (Title/Abstract)) OR (EGFR (Title/Abstract) AND mutation (Title) AND lung (Title/Abstract) AND methods (Title/ Abstract)) OR (EGFR mutation testing lung (All fields)) OR (EGFR (Title/Abstract) AND mutation (Title/Abstract) AND cytology (Title/Abstract)). Search results were filtered to exclude non-English language and review articles and the titles of the remaining 284 articles were reviewed to identify potentially relevant articles. Abstracts of such articles $(n=106)$ were reviewed and 59 studies that met one or both of the following criteria were selected for inclusion: (1) studies using 'standard' tumour tissue samples that assessed an EGFR mutation testing method and one or more 'comparator' methods; (2) studies reporting the use of cytology samples for EGFR mutation testing. Both groups excluded studies that only investigated non-TKI-sensitive EGFR mutations (ie, the exon 20 point mutation T790M alone) and those involving fewer than 20 samples.

\section{EGFR MUTATION TESTING METHODS IN TUMOUR TISSUE SAMPLES}

Our literature search identified 30 studies that assessed the utility of an EGFR mutation testing method and comparator method(s) using 20 or more tumour tissue samples (table 1). Methods were assigned into one of two broad categories: 'screening' methods that detect all mutations, including novel variants, in exons 18-21 and 'targeted' methods that detect specific, known mutations. The advantages and disadvantages of screening and targeted testing methods are summarised in table 2.

\section{Screening methods}

Table 1 includes six studies investigating the use of screening methods as alternatives to direct sequencing. In the study of Sueoka and colleagues, mutation testing results obtained by denaturing high-performance liquid chromatography (dHPLC) analysis of frozen tissue samples were consistent with those obtained by direct sequencing. ${ }^{20}$ These authors reported that the analysis time for dHPLC was a quarter of that for direct sequencing. When combined with a DNA endonuclease-based technique, HPLC was shown to have $100 \%$ analytical sensitivity and negative predictive value relative to direct sequencing. ${ }^{21}$ A technique related to dHPLC, high-resolution melting analysis (HRMA), exhibited 100\% sensitivity and 90\% specificity versus direct sequencing. ${ }^{22}$ Similarly high sensitivity and specificity versus sequencing was reported for HRMA by Takano and colleagues, although this group used HRMA as a targeted method. $^{23}$ Another study utilising HRMA reported identical EGFR mutation frequency rates to direct sequencing. ${ }^{24}$ An alternative next-generation sequencing methodology, massively parallel sequencing, was validated in a study by Querings and colleagues. $^{25}$ This group reported a $100 \%$ success rate of this method to detect low-frequency EGFR mutations compared with $89 \%$ for pyrosequencing-a non-electrophoretic sequencing technology employing luminometric detection-and $67 \%$ for direct sequencing. ${ }^{25}$

\section{Targeted methods}

The results of 24 studies that assessed targeted methods for detection of common EGFR mutations are shown in table 1. The majority of these studies investigated the use of PCR-based methods to specifically detect exon 19 deletions, the exon 21 L858R point mutation, and, in some cases, other less common but known EGFR mutations. ${ }^{26-40}$ In these studies, which varied in their use of frozen and/or FFPE tissue samples, virtually all samples testing positive for known mutations by direct sequencing were also detected by the PCR-based screening methods under investigation. Moreover, the targeted methods detected mutations in samples that had tested negative by direct sequencing. For example, the Amplification Refractory Mutation System (ARMS) - a commonly used method that discriminates between mutated and wild-type DNA by selectively amplifying mutation-containing target sequences-detected over twice as many exon 19 deletions and L858R mutations than direct sequencing in a study by our group. ${ }^{31}$ However, direct sequencing detected additional mutations not designed to be identified by the specific ARMS reactions. Another method commonly used is fragment length analysis; in the study of Pan and colleagues, this method detected more exon 19 deletions than direct sequencing. ${ }^{36}$ Pyrosequencing has also shown higher analytical sensitivity than direct sequencing for the two most common EGFR mutations; the accuracy of this method, however, was only maintained when samples contained at least $20 \%$ tumour cells. ${ }^{38}$ One novel technique adapted for PCR-based mutation detection is cationic conjugated polymer (CCP)-based fluorescence resonance energy transfer (FRET). ${ }^{40}$ This method, in which FRET probes bind to nested PCR-amplified products, detected EGFR mutations with comparable sensitivity (95\%) and specificity $(96 \%)$ to direct sequencing and RT-PCR. ${ }^{40}$

Non-PCR-based targeted methods listed in table 1 include Smart Amplification Process (SmartAMP), a one-step mutationdetection technology that enables precise amplification of only target sequences. ${ }^{42}$ In a study by Hoshi and colleagues, SmartAMP and direct sequencing showed high concordance 
Table 1 Studies of EGFR mutation testing methods using 'standard' tissue samples collected from patients with lung cancer

\begin{tabular}{|c|c|c|c|c|c|c|c|c|}
\hline Reference & $\begin{array}{l}\text { Mutation testing method } \\
\text { assessed (and comparator } \\
\text { method) }\end{array}$ & Activating mutations assessed & $\begin{array}{l}\text { No. of tissue } \\
\text { samples }\end{array}$ & $\begin{array}{l}\text { Tissue sample } \\
\text { preparation }\end{array}$ & $\begin{array}{l}\text { Macro- or } \\
\text { micro-dissected? }\end{array}$ & $\begin{array}{l}\text { Ethnicity of } \\
\text { study } \\
\text { population }\end{array}$ & $\begin{array}{l}\text { Mutation frequency (vs that with } \\
\text { comparator method)* }\end{array}$ & $\begin{array}{l}\text { Reported Se, Sp, } \\
\text { PPV, and NPV } \\
\text { relative to } \\
\text { comparator }\end{array}$ \\
\hline \multicolumn{9}{|l|}{ Screening methods } \\
\hline Sueoka et $a l^{20}$ & dHPLC (vs direct sequencing) & Exons $18-21$ & $\begin{array}{l}97 \text { (including } 16 \\
\text { PLE samples) }\end{array}$ & Frozen & NR & Japanese & $\begin{array}{l}\text { Any mutation: } 34(35 \%) \\
\text { (vs } 33(34 \%))\end{array}$ & NR \\
\hline Jänne et $a l^{21}$ & $\begin{array}{l}\text { DNA endonuclease (SURVEYOR) } \\
\text { and HPLC (vs direct sequencing) }\end{array}$ & Exons $18-21$ & $\begin{array}{l}160 \text { (more } \\
\text { samples were } \\
\text { analysed with } \\
\text { SURVEYOR/HPLC } \\
\text { only) }\end{array}$ & FFPE/frozen & $\begin{array}{l}\text { Macro-dissected } \\
\text { (91/117 FFPE } \\
\text { samples only) }\end{array}$ & $\begin{array}{l}\text { NR (study } \\
\text { performed in } \\
\text { USA) }\end{array}$ & $\begin{array}{l}\text { Any mutation: } 58(36 \%) \\
\text { (vs } 51(32 \%))\end{array}$ & $\begin{array}{l}\text { Se, } 100 \% ; \text { Sp, } \\
87 \% ; \text {; PPV, } 74 \% \text {; } \\
\text { NPV, } 100 \%\end{array}$ \\
\hline Do et $a l^{22}$ & HRMA (vs direct sequencing) & Exons $18-21$ & 200 & FFPE & Micro-dissected & $\begin{array}{l}\text { NR (study } \\
\text { performed in } \\
\text { Australia) }\end{array}$ & $\begin{array}{l}\text { Any mutation: } 118(59 \%) \\
\text { (vs } 73(37 \%))\end{array}$ & Se, $100 \%$; Sp, $90 \%$ \\
\hline Takano et a l $^{23}$ & HRMA (vs direct sequencing) $\dagger$ & $\begin{array}{l}\text { Exon } 19 \text { deletions and exon } 21 \\
\text { point mutation (L858R) }\end{array}$ & $\begin{array}{l}66 \text { (more samples } \\
\text { were analysed } \\
\text { with HRMA only) }\end{array}$ & FFPE/methanol-fixed & $\begin{array}{l}\text { Micro-dissected } \\
\text { (samples for } \\
\text { sequencing only) }\end{array}$ & $\begin{array}{l}\text { East Asian } \\
\text { patients }\end{array}$ & $\begin{array}{l}\text { Any screened mutation: } 34 \text { (52\%) for } \\
\text { FFPE and } 36(55 \%) \text { for } \\
\text { methanol-fixed (vs } 37(56 \%))\end{array}$ & $\begin{array}{l}\text { FFPE: Se, 92\%; Sp, } \\
100 \% ; \text { PPV, 100\%; } \\
\text { NPV, } 90 \% \\
\text { Methanol-fixed: Se, } \\
97 \% ; \text {; }, 100 \% ; \\
\text { PPV, } 100 \% ; \text { NPV, } \\
97 \%\end{array}$ \\
\hline Borràs et $a^{24}$ & HRMA (vs direct sequencing) & Exons 19-21 & 36 & FFPE & Macro-dissected & $\begin{array}{l}\text { NR (study } \\
\text { performed in } \\
\text { Spain) }\end{array}$ & $\begin{array}{l}\text { E746-A750: } 1(2.8 \%) \\
\text { (vs } 1(2.8 \%)) \\
\text { E746-T751insA: } 1(2.8 \%) \\
\text { (vs } 1(2.8 \%)) \\
\text { L858R: } 1(2.8 \%)(\text { vs } 1(2.8 \%)) \\
\text { P848L: } 1(2.8 \%)(\text { vs } 1(2.8 \%))\end{array}$ & NR \\
\hline Querings et $a^{25}$ & $\begin{array}{l}\text { Massively parallel sequencing (vs } \\
\text { direct sequencing and } \\
\text { pyrosequencing) }\end{array}$ & Exons $18-21$ & $\begin{array}{l}24 \text { (including } 3 \\
\text { cytology samples) }\end{array}$ & FFPE/frozen & NR & $\begin{array}{l}\text { NR (study } \\
\text { performed in } \\
\text { Germany) }\end{array}$ & $\begin{array}{l}\text { Any mutation: } 14(58.3 \%) \\
\text { (vs } 12(50.0 \%) \text { for pyrosequencing } \\
\text { and } 9(37.5 \%) \text { for direct sequencing) }\end{array}$ & $\begin{array}{l}\text { Se, } 100 \% \text { (vs } 89 \% \\
\text { for pyrosequencing } \\
\text { and } 67 \% \text { for direct } \\
\text { sequencing) }\end{array}$ \\
\hline \multicolumn{9}{|l|}{ Targeted methods } \\
\hline Endo et al ${ }^{26}$ & $\begin{array}{l}\text { TaqMan PCR (vs direct } \\
\text { sequencing) }\end{array}$ & 13 mutations across exons $18-21$ & $\begin{array}{l}94 \text { (more samples } \\
\text { were analysed } \\
\text { with TaqMan PCR } \\
\text { only) }\end{array}$ & FFPE & NR & $\begin{array}{l}\text { NR (study } \\
\text { performed in } \\
\text { Japan) }\end{array}$ & $\begin{array}{l}\text { Any screened mutation: } 27(28 \%) \text { (vs } \\
26(28 \%))\end{array}$ & NR \\
\hline Yatabe et $a^{27}$ & $\begin{array}{l}\text { Cycleave PCR (exon } 21 \text { (L858R)) } \\
\text { or fragment analysis (exon } 19 \\
\text { deletion) (vs direct sequencing) }\end{array}$ & $\begin{array}{l}\text { Exon } 19 \text { deletion (E746_A750) } \\
\text { and exon } 21 \text { point mutation } \\
\text { (L858R) }\end{array}$ & 195 & FFPE/frozen & Macro-dissected & $\begin{array}{l}\text { NR (study } \\
\text { performed in } \\
\text { Japan) }\end{array}$ & $\begin{array}{l}\text { E746_A750: } 38 \text { (19\%) } \\
\text { (vs } 39(20 \%)) \\
\text { L858R:33 (17\%) (vs } 32(16 \%))\end{array}$ & NR \\
\hline Ohnishi et $a l^{28}$ & $\begin{array}{l}\text { Mutation-specific PCR (vs direct } \\
\text { sequencing) }\end{array}$ & $\begin{array}{l}\text { Exon } 19 \text { deletion (E746_A750) } \\
\text { and exon } 21 \text { point mutation } \\
\text { (L858R) }\end{array}$ & 62 & Frozen & NR & $\begin{array}{l}\text { NR (study } \\
\text { performed in } \\
\text { Japan) }\end{array}$ & $\begin{array}{l}\text { E746_A750: } 8(13 \%) \\
\text { (vs 8 (13\%)) } \\
\text { L858R:14 (23\%) (vs } 11(18 \%))\end{array}$ & NR \\
\hline Asano et $a^{29}$ & $\begin{array}{l}\text { Mutant-enriched PCR (vs } \\
\text { non-enriched PCR and direct } \\
\text { sequencing) }\end{array}$ & $\begin{array}{l}\text { Exon } 19 \text { deletions and exon } 21 \\
\text { point mutation (L858R) }\end{array}$ & 108 & Frozen & NR & $\begin{array}{l}\text { NR (study } \\
\text { performed in } \\
\text { Japan) }\end{array}$ & $\begin{array}{l}\text { Exon } 19 \text { deletions: } 17 \text { ( } 16 \%) \text { (vs } 16 \\
\text { (15\%) for both non-enriched PCR and } \\
\text { direct sequencing) } \\
\text { L858R: } 20 \text { (19\%) vs (17 }(16 \%) \text { for } \\
\text { both non-enriched PCR and direct } \\
\text { sequencing) }\end{array}$ & NR \\
\hline Otani et $a \beta^{30}$ & $\begin{array}{l}\text { Mutant-enriched PCR (vs } \\
\text { non-enriched PCR and direct } \\
\text { sequencing) }\end{array}$ & $\begin{array}{l}\text { Exon } 19 \text { deletions and exon } 21 \\
\text { point mutation (L858R) }\end{array}$ & 26 & Frozen & NR & $\begin{array}{l}\text { NR (study } \\
\text { performed in } \\
\text { Japan) }\end{array}$ & $\begin{array}{l}\text { Exon } 19 \text { deletions: } 3(12 \%) \text { (vs } 3 \\
\text { (11\%) for both non-enriched PCR and } \\
\text { direct sequencing) } \\
\text { L858R: } 11 \text { ( } 42 \%) \text { (vs } 6(23 \%) \text { for both } \\
\text { non-enriched PCR and direct } \\
\text { sequencing) }\end{array}$ & NR \\
\hline
\end{tabular}


Table 1 Continued

\begin{tabular}{|c|c|c|c|c|c|c|c|c|}
\hline Reference & $\begin{array}{l}\text { Mutation testing method } \\
\text { assessed (and comparator } \\
\text { method) }\end{array}$ & Activating mutations assessed & $\begin{array}{l}\text { No. of tissue } \\
\text { samples }\end{array}$ & $\begin{array}{l}\text { Tissue sample } \\
\text { preparation }\end{array}$ & $\begin{array}{l}\text { Macro- or } \\
\text { micro-dissected? }\end{array}$ & $\begin{array}{l}\text { Ethnicity of } \\
\text { study } \\
\text { population }\end{array}$ & $\begin{array}{l}\text { Mutation frequency (vs that with } \\
\text { comparator method)* }\end{array}$ & $\begin{array}{l}\text { Reported Se, Sp, } \\
\text { PPV, and NPV } \\
\text { relative to } \\
\text { comparator }\end{array}$ \\
\hline Ellison et $\left.a\right|^{31}$ & ARMS (vs direct sequencing) & $\begin{array}{l}\text { Exon } 19 \text { deletion (E746_A750) } \\
\text { and exon } 21 \text { point mutation } \\
\text { (L858R) }\end{array}$ & 215 & FFPE & Macro-dissected & NR & $\begin{array}{l}\text { E746_A750: } 9(4 \%) \\
\text { (vs } 4(2 \%)) \\
\text { L858R: } 9(4 \%) \text { (vs } 4(2 \%))\end{array}$ & NR \\
\hline Zhao et $a l^{32}$ & $\begin{array}{l}\text { Mutant-enriched ARMS TaqMan } \\
\text { PCR (vs direct sequencing) }\end{array}$ & $\begin{array}{l}\text { Exon } 19 \text { deletion (E746_A750) } \\
\text { and exon } 21 \text { point mutation } \\
\text { (L858R) }\end{array}$ & 31 & FFPE & NR & $\begin{array}{l}\text { NR (study } \\
\text { performed in } \\
\text { China) }\end{array}$ & $\begin{array}{l}\text { E746_A750: } 5 \text { (16\%) } \\
\text { (vs 3 (6\%)) } \\
\text { L858R: } 6(19 \%) \text { (vs } 5(16 \%))\end{array}$ & NR \\
\hline Naoki et al ${ }^{33}$ & PCR-Invader (vs DNA sequencing) & $\begin{array}{l}\text { Exon } 18 \text { point mutations (G719A/ } \\
\text { C/S), exon } 19 \text { deletions, exon } 20 \\
\text { point mutation (S768I), exon } 21 \\
\text { point mutations (L858R and } \\
\text { L861Q) }\end{array}$ & $\begin{array}{l}49 \text { (plus } 4 \text { PLE } \\
\text { and } 1 \text { PCE) }\end{array}$ & $\begin{array}{l}\text { FFPE (tissue } \\
\text { samples only) }\end{array}$ & Macro-dissected & Japanese & $\begin{array}{l}\text { Any of the screened mutations: } 28 \\
(52 \%) \\
\text { (vs } 19(35 \%))\end{array}$ & NR \\
\hline Kawada et a $\beta^{34}$ & PCR-RFLP (vs direct sequencing) & $\begin{array}{l}\text { Exon } 18 \text { point mutation (G719X), } \\
\text { exon } 19 \text { deletions and exon } 21 \\
\text { point mutations (L858R and } \\
\text { L861Q) }\end{array}$ & $\begin{array}{l}91 \text { (plus } 14 \text { PLE, } \\
3 \text { PCE and } 1 \\
\text { sputum) }\end{array}$ & Frozen & NR & $\begin{array}{l}\text { NR (study } \\
\text { performed in } \\
\text { Japan) }\end{array}$ & $\begin{array}{l}\text { Any of the screened mutations: } 37 \\
\text { (34\%) } \\
\text { (vs } 36(33 \%))\end{array}$ & NR \\
\hline Molina-Vila et al ${ }^{35}$ & $\begin{array}{l}\text { Length analysis for exon } 19 \\
\text { deletions and TaqMan assay for } \\
\text { exon } 21 \text { point mutation (vs direct } \\
\text { sequencing) }\end{array}$ & $\begin{array}{l}\text { Exon } 19 \text { deletions and exon } 21 \\
\text { point mutations (L858R and } \\
\text { L861Q) }\end{array}$ & $\begin{array}{l}217 \text { (includes } 72 \\
\text { cytology samples) }\end{array}$ & FFPE/fresh & Micro-dissected & $\begin{array}{l}\text { NR (study } \\
\text { performed in } \\
\text { Spain) }\end{array}$ & $\begin{array}{l}\text { Exon } 19 \text { deletions: } 25(12 \%) \text { (vs } 25 \\
(12 \%)) \\
\text { L858R: } 11(5 \%) \text { (vs } 11(5 \%)) \\
\text { L861Q: } 1(0.5 \%) \\
\text { (vs } 1(0.5 \%))\end{array}$ & NR \\
\hline Pan et $a{ }^{36}$ & $\begin{array}{l}\text { Length analysis (exon } 19 \\
\text { deletions) and PCR-RFLP (exon } 21 \\
\text { (L858R)) (vs direct sequencing) }\end{array}$ & $\begin{array}{l}\text { Exon } 19 \text { deletions and exon } 21 \\
\text { point mutation (L858R) }\end{array}$ & 39 & NR & NR & $\begin{array}{l}\text { NR (study } \\
\text { performed in } \\
\text { USA) }\end{array}$ & $\begin{array}{l}\text { Exon } 19 \text { deletions: } 15(38 \%) \text { (vs } 13 \\
(33 \%)) \\
\text { L858R: } 14(36 \%) \\
\text { (vs } 12(31 \%))\end{array}$ & NR \\
\hline Ikeda et $\left.a\right|^{37}$ & $\begin{array}{l}\text { In-situ LAMP with ARMS (vs } \\
\text { PCR-RFLP) }\end{array}$ & Exon 21 point mutation (L858R) & 26 & Paraffin-embedded & NR & $\begin{array}{l}\text { NR (study } \\
\text { performed in } \\
\text { Japan) }\end{array}$ & $\begin{array}{l}\text { L858R: } 15(58 \%) \\
\text { (vs } 12(46 \%))\end{array}$ & NR \\
\hline Dufort et $\left.a\right|^{38}$ & $\begin{array}{l}\text { Pyrosequencing } \text { (vs direct } \\
\text { sequencing) }\end{array}$ & $\begin{array}{l}\text { Exon } 19 \text { deletions and exon } 21 \\
\text { point mutation (L858R) }\end{array}$ & $\begin{array}{l}58 \text { (more samples } \\
\text { were analysed } \\
\text { with } \\
\text { pyrosequencing } \\
\text { only) }\end{array}$ & FFPE/others & NR & $\begin{array}{l}\text { NR (study } \\
\text { performed in } \\
\text { France) }\end{array}$ & $\begin{array}{l}\text { Exon } 19 \text { deletions: } 11(19 \%) \text { (vs } 9 \\
(16 \%)) \\
\text { L858R: } 5(9 \%) \text { (vs } 4(7 \%))\end{array}$ & NR \\
\hline Han et $a \beta^{39}$ & $\begin{array}{l}\text { PCR-PNA clamp (vs direct } \\
\text { sequencing) }\end{array}$ & $\begin{array}{l}\text { Exon } 19 \text { deletions, exon } 20 \\
\text { insertions, and exon } 21 \text { point } \\
\text { mutation ( }(\mathrm{L} 858 \mathrm{R} \text { and } \mathrm{L} 816 \mathrm{Q})\end{array}$ & $\begin{array}{l}23 \text { (and } 41 \\
\text { pleural effusion } \\
\text { samples) }\end{array}$ & FFPE & No & $\begin{array}{l}\text { NR (study } \\
\text { performed in } \\
\text { South Korea) }\end{array}$ & $\begin{array}{l}\text { Any of the screened mutations: } 16 \\
(69.6 \%)(\text { vs } 12(52.2 \%)) \text { for adequate } \\
\text { biopsy specimens and } 12(52.2 \%) \\
\text { (vs } 12(52.2 \%)) \text { for matched } \\
\text { surgically resected specimens }\end{array}$ & NR \\
\hline Yang et $a l^{40}$ & $\begin{array}{l}\text { PCR/CCP-based FRET (vs direct } \\
\text { sequencing and RT-PCR) }\end{array}$ & Exon 21 point mutation (L858R) & 48 & FFPE & No & $\begin{array}{l}\text { NR (study } \\
\text { performed in } \\
\text { China) }\end{array}$ & $\begin{array}{l}\text { L858R: } 20(41.7 \%) \text { (vs } 19(39.6 \%) \text { for } \\
\text { direct sequencing and } 21(43.8 \% \text { for } \\
\text { RT-PCR)) }\end{array}$ & $\begin{array}{l}\text { Se, } 95.2 \% ; \mathrm{Sp} \\
96.3 \%\end{array}$ \\
\hline Hoshi et al ${ }^{41}$ & SmartAmp (vs direct sequencing) & $\begin{array}{l}\text { Exon } 18 \text { point mutation (G719S), } \\
\text { exon } 19 \text { deletions and exon } 21 \\
\text { point mutation (L858R) }\end{array}$ & 45 & Frozen & NR & $\begin{array}{l}\text { NR (study } \\
\text { performed in } \\
\text { Japan) }\end{array}$ & $\begin{array}{l}\text { G719S: } 0(0 \%) \text { (vs } 0(0 \%)) \\
\text { Exon } 19 \text { deletions: } 5(11 \%) \\
\text { (vs } 5(11 \%)) \\
\text { L858R: } 5(11 \%) \text { (vs } 4(9 \%))\end{array}$ & NR \\
\hline Miyamae et $a l^{42}$ & $\begin{array}{l}\text { Conventional and PNA-clamp } \\
\text { SmartAmp2 (vs direct sequencing) }\end{array}$ & $\begin{array}{l}\text { Exon } 19 \text { deletions and exon } 21 \\
\text { point mutation (L858R) }\end{array}$ & 43 & $\begin{array}{l}\text { FFPE and paired } \\
\text { frozen }\end{array}$ & NR & $\begin{array}{l}\text { NR (study } \\
\text { performed in } \\
\text { Japan) }\end{array}$ & $\begin{array}{l}\text { Exon } 19 \text { deletions: } 18(42 \%) \text { (vs } 12 \\
\text { (28\%) for frozen and FFPE) } \\
\text { L858R: } 12(28 \%) \text { (vs } 5(12 \%) \text { ) for } \\
\text { frozen and } 11(26 \%) \\
\text { (vs } 3(7 \%)) \text { for FFPE }\end{array}$ & NR \\
\hline
\end{tabular}


Table 1 Continued

\begin{tabular}{|c|c|c|c|c|c|c|c|c|}
\hline Reference & $\begin{array}{l}\text { Mutation testing method } \\
\text { assessed (and comparator } \\
\text { method) }\end{array}$ & Activating mutations assessed & $\begin{array}{l}\text { No. of tissue } \\
\text { samples }\end{array}$ & $\begin{array}{l}\text { Tissue sample } \\
\text { preparation }\end{array}$ & $\begin{array}{l}\text { Macro- or } \\
\text { micro-dissected? }\end{array}$ & $\begin{array}{l}\text { Ethnicity of } \\
\text { study } \\
\text { population }\end{array}$ & $\begin{array}{l}\text { Mutation frequency (vs that with } \\
\text { comparator method)* }\end{array}$ & $\begin{array}{l}\text { Reported Se, Sp, } \\
\text { PPV, and NPV } \\
\text { relative to } \\
\text { comparator }\end{array}$ \\
\hline Araki et $a l^{43}$ & $\begin{array}{l}\text { PNA-clamp SmartAmp2 (vs direct } \\
\text { sequencing, PNA-enriched } \\
\text { sequencing, and SmartAmp2) }\end{array}$ & Exon 19 deletions & 172 & Frozen & No & Asian & $\begin{array}{l}\text { Exon } 19 \text { deletions: } 39 \text { ( } 22.7 \%) \text { (vs } 30 \\
(17.4 \%) \text { for direct sequencing and } 38 \\
(22.1 \%) \text { for PNA-enriched sequencing } \\
\text { and } 12(7.0 \%) \text { for SmartAmp2) }\end{array}$ & NR \\
\hline Kozu et al ${ }^{44}$ & IHC (vs HRMA) & $\begin{array}{l}\text { Exon } 19 \text { deletions and exon } 21 \\
\text { point mutation (L858R) }\end{array}$ & $\begin{array}{l}577 \text { (including } 36 \\
\text { cytological } \\
\text { smears) }\end{array}$ & Frozen or MFPE & $\begin{array}{l}\text { No (but tumour } \\
\text { regions selected for } \\
\text { TMA and IHC } \\
\text { analysis) }\end{array}$ & Japanese & $\begin{array}{l}\text { Exon } 19 \text { deletions: } 59(10 \%) \text { (vs } 135 \\
(23 \%)) \\
\text { L858R: } 139(24 \%) \\
\text { (vs } 172(30 \%))\end{array}$ & $\begin{array}{l}\text { Exon } 19 \text { deletions: } \\
\text { Se, } 42 \% ; \text {;p, } 100 \% \\
\text { L858R: Se, } 76 \% ; \\
\text { Sp. } 98 \%\end{array}$ \\
\hline Brevet et $a l^{45}$ & $\begin{array}{l}\text { IHC (vs fragment analysis for exon } \\
19 \text { deletion (mutant-enriched PCR } \\
\text { assay for discordant results) or } \\
\text { PCR-RFLP for L858R } \\
\text { (mass-spectrometry-based DNA } \\
\text { analysis for discordant results)) }\end{array}$ & $\begin{array}{l}\text { Exon } 19 \text { deletions and exon } 21 \\
\text { point mutation (L858R) }\end{array}$ & 194 & FFPE & Macro-dissected & $\begin{array}{l}\text { NR (study } \\
\text { performed in } \\
\text { USA) }\end{array}$ & $\begin{array}{l}\text { E746_A750: } 22(11 \%) \\
\text { (vs } 20(10 \%)) \\
\text { Other exon 19 deletions: } 25(13 \%) \\
\text { (vs } 31(16 \%)) \\
\text { L858R: } 22(11 \%) \\
\text { (vs } 21(11 \%))\end{array}$ & $\begin{array}{l}\text { E746_A750 } \\
\text { deletion: Se, } 100 \% \\
\text { Other exon } 19 \\
\text { deletions: } \mathrm{Se}, 74 \% \\
\text { E746_A750 } \\
\text { deletion and other } \\
\text { exon } 19 \text { deletions: } \\
\text { Sp, } 98.8 \% \\
\text { L } 858 \mathrm{R}: \mathrm{Se}, 95 \% \text {; } \\
\text { Sp. } 99 \%\end{array}$ \\
\hline Ilie et $a{ }^{46}$ & IHC (vs direct sequencing) & Exon 19 deletions & 61 & $\begin{array}{l}\text { FFPE (direct } \\
\text { sequencing } \\
\text { performed on frozen } \\
\text { samples) }\end{array}$ & $\begin{array}{l}\text { No (but tumour } \\
\text { regions selected for } \\
\text { TMA and IHC } \\
\text { analysis) }\end{array}$ & Caucasian & $\begin{array}{l}\text { E746_A750: } 12(20 \%) \\
\text { (vs } 8(13 \%)) \\
\text { All exon } 19 \text { deletions: } 13 \text { (21\%) (vs } \\
10(16 \%))\end{array}$ & $\begin{array}{l}\text { Se, } 23 \% ; \text { NPV, } 49 \% \\
\text { (calculated using } \\
\text { results from direct } \\
\text { sequencing plus } \\
\text { other methods) }\end{array}$ \\
\hline Kato et $a l^{47}$ & IHC (vs direct sequencing) & $\begin{array}{l}\text { Exon } 19 \text { deletion (E746_A750) } \\
\text { and exon } 21 \text { point mutation } \\
\text { (L858R) }\end{array}$ & 70 & NR & $\begin{array}{l}\text { No (but tumour } \\
\text { regions selected for } \\
\text { TMA and IHC } \\
\text { analysis) }\end{array}$ & Japanese & $\begin{array}{l}\text { E746_A750: } 9(13 \%) \\
\text { (vs } 11(16 \%)) \\
\text { L858R: } 11(16 \%) \\
\text { (vs } 12(17 \%))\end{array}$ & $\begin{array}{l}\text { E746_A750: Se, } \\
82 \% ; \text { Sp, } 100 \% ; \\
\text { PPV, } 100 \% ; \text { NPV, } \\
96.7 \% \\
\text { L858R : Se, } 75 \% ; \\
\text { Sp, } 97 \% ; \text { PPV, } \\
82 \% ; \text { NPV, } 95 \%\end{array}$ \\
\hline Nakamura et al ${ }^{48}$ & $\begin{array}{l}\text { IHC (vs PNA-LNA PCR clamp/ } \\
\text { direct sequencing) }\end{array}$ & $\begin{array}{l}\text { Exon } 19 \text { deletion (E746_A750) } \\
\text { and exon } 21 \text { point mutation } \\
\text { (L858R) }\end{array}$ & 20 & FFPE & No & $\begin{array}{l}\text { NR (study } \\
\text { performed in } \\
\text { Japan) }\end{array}$ & $\begin{array}{l}\text { E746_A750: } 4(20 \%) \\
\text { (vs 3 }(15 \%)) \\
\text { L858R: } 4(20 \%) \text { (vs } 5(25 \%))\end{array}$ & Se, $92 \% ;$ Sp, $100 \%$ \\
\hline Simonetti et al ${ }^{49}$ & $\begin{array}{l}\text { IHC (vs fragment analysis, } \\
\text { TaqMan assay, and direct } \\
\text { sequencing) }\end{array}$ & $\begin{array}{l}\text { Exon } 19 \text { deletions and exon } 21 \\
\text { point mutations (L858R and } \\
\text { L816Q) }\end{array}$ & 78 & FFPE & Micro-dissected & Caucasian & $\begin{array}{l}\text { E746_A750: } 17(22 \%) \\
\text { (vs } 17(22 \%)) \\
\text { Other exon } 19 \text { deletions: } \\
3(4 \%)(\text { vs } 12(15 \%)) \\
\text { L858R: } 25(32 \%) \\
\text { (vs } 25(32 \%)) \\
\text { L816Q: } 0(0 \%) \\
\text { (vs } 2(3 \%))\end{array}$ & NR \\
\hline
\end{tabular}

Only studies identified by our literature search and meeting the criteria described in the Methods are listed.

*In many studies, samples were selected and/or purposely enriched to include a higher number of mutated samples; therefore, mutation frequency data should not be considered representative of the general population.

tHRMA was used as a targeted method in this study.

$\neq$ Pyrosequencing tends to be performed in a semi-targeted manner.

ARMS, Amplification Refractory Mutation System; CCP-based FRET, cationic conjugated polymer-based fluorescence resonance energy transfer; dHPLC, denaturing high-performance liquid chromatography; EGFR, epidermal growth factor receptor: FFPE, formalin-fixed paraffin-embedded; HPLC, high-performance liquid chromatography; HRMA, high-resolution melting analysis; IHC, immunohistochemistry; LAMP, loop-mediated isothermal amplification; MFPE, methanol-fixed paraffin-embedded; NPV, negative predictive value; NR, not reported; PCE, pericardial effusion; PCR-RFLP, PCR-restriction fragment length polymorphism; PLE, pleural effusion; PNA, peptide nucleic acid; PNA-LNA, PNA-locked nucleic acid; PPV, positive predictive value;

Se, sensitivity; SmartAmp2, smart amplification process V.2; Sp, specificity; TMA, tissue microarray. 
Table 2 Advantages and disadvantages of screening and targeted methods for EGFR mutation testing

\begin{tabular}{|c|c|c|}
\hline & $\begin{array}{l}\text { Screening methods (samples screened for all EGFR mutations, } \\
\text { known and novel variants) }\end{array}$ & $\begin{array}{l}\text { Targeted methods (samples analysed for known EGFR mutations } \\
\text { only) }\end{array}$ \\
\hline Advantages & $\begin{array}{l}\text { All mutations, including novel mutations, may be detected (analytical } \\
\text { sensitivity) } \\
\text { Direct sequencing technology is widely available }\end{array}$ & $\begin{array}{l}\text { Less time-consuming than the screening method direct sequencing, } \\
\text { leading to reduced turnaround times } \\
\text { Sensitivity (limit of detection) tends to be higher than with screening } \\
\text { methods } \\
\text { - Technology is fairly widely available }\end{array}$ \\
\hline Disadvantages & $\begin{array}{l}\text { Sensitivity tends to be lower than with targeted methods } \\
\text { Often require enrichment of tumour cells by macro- or micro-dissection } \\
\text { Experienced operators needed } \\
\text { Tend to be more labour intensive and time consuming than targeted } \\
\text { methods, leading to longer turnaround times }\end{array}$ & $\begin{array}{l}\text { Rare mutations not assayed for are not detected } \\
\text { Reagents may be more expensive than for screening methods such as } \\
\text { direct sequencing }\end{array}$ \\
\hline
\end{tabular}

when used to assess frozen clinical samples for the two most common EGFR mutations and the exon 18 G719S point mutation. $^{41}$ A modification of this technique, peptide nucleic acid (PNA)-clamp SmartAmp2, in which oligomers of PNA (a synthetic DNA analogue) bind to wild-type DNA sequences spanning mutational hotspots, preferentially allowing for mutant DNA amplification, ${ }^{39}$ has been investigated in two studies. ${ }^{42} 43$ One study found that PNA-clamp SmartAmp2 was more sensitive than direct sequencing at detecting the two main EGFR mutations using both frozen and FFPE tissue samples. ${ }^{42}$ Similarly, a second study reported greater sensitivity of this technique compared with direct sequencing, PNA-enriched sequencing, and conventional SmartAmp $2 .{ }^{43}$

Several of the studies listed in table 1 used immunohistochemistry (IHC) for the targeted mutation analysis of tissue samples. ${ }^{44-49}$ These studies utilised two mutant-specific rabbit monoclonal antibodies directed against the exon 19 A746_A750 deletion and L858R, and most reported high sensitivity and specificity for mutant-specific IHC versus direct sequencing and/or other comparator methods.

\section{USE OF CYTOLOGY SAMPLES FOR EGFR MUTATION TESTING}

In total, 33 original studies reporting the use of cytology samples for EGFR mutation testing were identified by our literature search (table 3). Commonly tested cytology samples included tissue samples collected during diagnosis (eg, fine needle aspirate (FNA) samples acquired via minimally invasive biopsy procedures, which often contain high proportions of tumour cells) or liquid-based samples obtained from patients experiencing common complications of lung cancer (eg, PLE, which often have low tumour cell content). Use of sensitive mutation testing methods is warranted when cytology samples with low tumour content are used. In two separate studies, EGFR mutations detected by mutant-enriched PCR in some PLE samples were not detected by non-enriched assays. ${ }^{29} 50$ Similarly, the sensitive ARMS technique has been shown to detect mutations in PLE samples not identified via direct sequencing. ${ }^{51}$ Interestingly, the detection rate of EGFR mutations with direct sequencing improved from $45 \%$ when using genomic DNA to $67 \%$ when using tumour-derived RNA isolated from PLE samples as an alternative source. ${ }^{52}$ ARMS was also more sensitive than direct sequencing in studies utilising transbronchial FNA. ${ }^{53}$ Our search showed that the use of FNA for detection of EGFR mutations has been relatively widely investigated (table 3). Several FNA-generating techniques used for the diagnosis and staging of lung cancers have attracted particular interest in this regard: endobronchial ultrasound-guided fine needle aspiration (EBUS-FNA), trans-oesophageal ultrasoundguided fine needle aspiration (EUS-FNA), and CT-guided FNA. Cytology samples obtained via these techniques were successfully assessed for EGFR mutations using direct sequencing. ${ }^{545}$ Other studies have reported the successful use of EBUS-FNA and/or EUS-FNA samples with real-time PCR, ${ }^{56} 57$ COLD-PCR, ${ }^{58}$ PNA-locked nucleic acid (LNA) PCR clamp, ${ }^{59}$ or loop-hybrid mobility shift assay. ${ }^{60}$

\section{DISCUSSION AND FUTURE PERSPECTIVES}

A variety of methods have been employed as potential alternatives to the historical standard for EGFR mutation testing, direct sequencing. In practice, the choice of testing method should be based primarily on the nature of the sample to be tested including tumour content (particularly for cytology material), the testing laboratory's expertise and available equipment, and whether detection of known activating EGFR mutations only is considered sufficient (figure 1).

Reflecting its position as the historical standard, direct sequencing was used as the comparator method in many of the studies identified by our search. The variability observed between studies when comparing sequencing to other mutation testing methods may be due to technical differences, such as primers or reagents used by individual laboratories. Perhaps the primary limitation of direct sequencing is its low sensitivity; indeed, a mutation should generally be present in approximately $20 \%$ of all DNA in a sample to be reliably detected by this method. $^{78} 79$ In our experience, the approximate tumour content of lung tissue samples can range from 5 to $100 \%$. Therefore, a limit of detection of $20 \%$ means that direct sequencing may offer insufficient sensitivity. ${ }^{80}$ Preparation of samples by macro-dissection or laser capture micro-dissection prior to DNA extraction, however, can enrich tumour cell content and thereby increase the utility of sequencing as a routine pretreatment test. ${ }^{81}$ While relatively cost-effective from a reagent perspective compared with targeted methods, ${ }^{82}$ these preparatory enrichment methods are labour intensive and time consuming and provide a relatively marginal improvement. Alternative screening methods to direct sequencing include dHPLC and HRMA. Although dHPLC appears to have higher analytical sensitivity than direct sequencing, ${ }^{20}$ dHPLC requires extra processing steps after PCR amplification and the use of expensive instrumentation. $^{22}$ HRMA has been proposed as an alternative, and is able to detect mutant genes at levels of $2.5-10 \% .^{22} 24$ HRMA is relatively inexpensive; however, samples testing positive by HRMA must then be analysed by direct sequencing to 
Table 3 Studies of EGFR mutation testing methods using cytology samples collected from patients with lung cancer

\begin{tabular}{|c|c|c|c|}
\hline Reference & $\begin{array}{l}\text { Cytology samples (no. of samples for mutation } \\
\text { analysis (fail data if available)) }\end{array}$ & $\begin{array}{l}\text { Method(s) of EGFR mutation testing } \\
\text { assessed }\end{array}$ & $\begin{array}{l}\text { Authors' conclusions on use of cytology samples } \\
\text { for EGFR mutation testing }\end{array}$ \\
\hline Asano et $a l^{29}$ & $\begin{array}{l}\text { Cell-free PLE ( } n=20), \text { CT-guided needle lung biopsies } \\
(n=18)\end{array}$ & $\begin{array}{l}\text { Mutant-enriched PCR versus } \\
\text { non-enriched PCR and direct } \\
\text { sequencing }\end{array}$ & $\begin{array}{l}\text { Mutant-enriched PCR detected EGFR alterations that } \\
\text { were not identified with a non-enriched assay }\end{array}$ \\
\hline $\begin{array}{l}\text { Fassina } \\
\text { et a }\left.\right|^{61}\end{array}$ & TTNA samples $(n=77)$ & HRMA versus direct sequencing & $\begin{array}{l}\text { HRMA of TTNA samples was accurate, fast, easy, } \\
\text { cheap, and reliable for the detection of common EGFR } \\
\text { mutations }\end{array}$ \\
\hline $\begin{array}{l}\text { Hlinkova } \\
\text { et } a /^{62}\end{array}$ & $\begin{array}{l}\text { Cytological samples obtained by endobronchial } \\
\text { brushing }(n=53)\end{array}$ & $\begin{array}{l}\text { HRMA versus direct sequencing (with } \\
\text { mutant-enriched PCR if }<25 \% \text { tumour } \\
\text { cells) }\end{array}$ & $\begin{array}{l}\text { HRMA in combination with mutant-enriched PCR is a } \\
\text { sensitive method for mutation detection in cytology } \\
\text { samples }\end{array}$ \\
\hline $\begin{array}{l}\text { Horiike } \\
\text { et }\left.a\right|^{53}\end{array}$ & $\begin{array}{l}\text { Transbronchial FNA ( } \mathrm{n}=93 \text { (10 fails }(11 \%) \text { with direct } \\
\text { sequencing; } 0 \text { fails with Scorpion ARMS)) }\end{array}$ & $\begin{array}{l}\text { Scorpion ARMS versus direct } \\
\text { sequencing }\end{array}$ & $\begin{array}{l}\text { Both methods detected EGFR mutations in } \\
\text { transbronchial FNA samples although Scorpion ARMS } \\
\text { was more sensitive }\end{array}$ \\
\hline $\begin{array}{l}\text { Kawahara } \\
\text { et a } a^{/ 3}\end{array}$ & $\operatorname{PLE}(n=21), \operatorname{CSF}(n=2)$, and ascites $(n=1)$ & $\begin{array}{l}\text { Immunocytochemistry versus PNA-LNA } \\
\text { PCR clamp }\end{array}$ & $\begin{array}{l}\text { EGFR mutations were detected in PLE and CSF with } \\
100 \% \text { sensitivity using antibodies specific for the exon } \\
19 \text { deletion E746_A750 and the exon } 21 \text { point } \\
\text { mutation L858R }\end{array}$ \\
\hline $\begin{array}{l}\text { Kimura } \\
\text { et } a l^{64}\end{array}$ & Cell-free PLE $(n=43)$ & Direct sequencing & DNA in PLE can be used to detect EGFR mutations \\
\hline $\begin{array}{l}\text { Kimura } \\
\text { et } a^{51}\end{array}$ & Cell-free PLE $(n=24)$ & $\begin{array}{l}\text { Scorpion ARMS versus direct } \\
\text { sequencing }\end{array}$ & $\begin{array}{l}\text { DNA in PLE can be used to detect EGFR mutations. } \\
\text { Scorpion ARMS was more sensitive than direct } \\
\text { sequencing }\end{array}$ \\
\hline Kozu et al ${ }^{44}$ & $\begin{array}{l}\text { Imprint cytological smears from fresh-cut surface of } \\
\text { resected tumour specimens }(n=36)\end{array}$ & HRMA versus IHC & $\begin{array}{l}\text { (Results of cytology sample analyses were combined } \\
\text { with those of } 541 \text { tissue specimens (see table 2)) }\end{array}$ \\
\hline Lim et $a l^{65}$ & FNA $(n=29)$ & $\begin{array}{l}\text { Whole genome amplification followed } \\
\text { by direct sequencing }\end{array}$ & $\begin{array}{l}\text { EGFR mutations were identified using direct sequencing } \\
\text { of whole genome-amplified genomic DNA from } \\
\text { low-volume FNA samples }\end{array}$ \\
\hline $\begin{array}{l}\text { Lozano } \\
\text { et al/66 }\end{array}$ & $\begin{array}{l}\text { Primary lung tumour FNA ( } n=68) \text {, metastatic lymph } \\
\text { node FNA ( } n=10) \text {, bone metastases FNA ( } n=3) \text {, left } \\
\text { adrenal metastasis FNA }(n=1), \operatorname{PLE}(n=6), P C E(n=1) \text {, } \\
\text { and bronchoalveolar lavage }(n=1)\end{array}$ & Direct sequencing & $\begin{array}{l}\text { Assessment of EGFR mutation in cytology samples is } \\
\text { feasible and comparable with biopsy results }\end{array}$ \\
\hline $\begin{array}{l}\text { Nakajima } \\
\text { et } a^{60}\end{array}$ & $\begin{array}{l}\text { EBUS-TBNA samples from metastatic lymph nodes } \\
(\mathrm{n}=43)\end{array}$ & $\begin{array}{l}\text { Loop-hybrid mobility shift assay } \\
\text { confirmed by direct sequencing }\end{array}$ & $\begin{array}{l}\text { EGFR mutations can easily be detected in metastatic } \\
\text { lymph nodes samples by EBUS-TBNA }\end{array}$ \\
\hline Oshita et $a^{67}$ & $\begin{array}{l}\text { Cytology samples obtained by transbronchial abrasion } \\
(n=52)(2 \text { fails }(4 \%))\end{array}$ & Loop-hybrid mobility shift assay & $\begin{array}{l}\text { Assessment of EGFR mutations in cytological samples } \\
\text { is feasible and comparable with biopsy results }\end{array}$ \\
\hline Otani et $a l^{30}$ & Biopsy needle wash fluid ( $n=26$ ) & $\begin{array}{l}\text { Mutant-enriched PCR versus } \\
\text { non-enriched PCR versus direct } \\
\text { sequencing }\end{array}$ & $\begin{array}{l}\text { EGFR mutations can be detected in the wash fluid of } \\
\text { CT-guided biopsy needles }\end{array}$ \\
\hline $\begin{array}{l}\text { Rekhtman } \\
\text { et } a^{68}\end{array}$ & $\begin{array}{l}\text { Transbronchial/transthoracic FNA ( } n=67) \text {, extrathoracic } \\
\text { FNA }(n=29) \text {, PLE }(n=29) \text {, and bronchial brush/wash } \\
(n=3)(2 \text { failures }(2 \%))\end{array}$ & Length analysis and PCR-RFLP & $\begin{array}{l}\text { EGFR analysis is feasible in routinely processed } \\
\text { cytology samples }\end{array}$ \\
\hline Savic et a/ ${ }^{69}$ & $\begin{array}{l}\text { Transbronchial FNA ( } n=35) \text {, PLE }(n=16) \text {, bronchial } \\
\text { washing }(n=15) \text {, bronchial brushes }(n=13) \text {, and } \\
\text { bronchoalveolar lavage }(n=5)\end{array}$ & PCR-direct sequencing & EGFR analyses are applicable to cytology specimens \\
\hline $\begin{array}{l}\text { Schuurbiers } \\
\text { et } a l^{54}\end{array}$ & EBUS-/EUS-FNA samples ( $n=35$ (8 fails $(23 \%)$ ) & Direct sequencing & $\begin{array}{l}\text { Molecular analysis for EGFR mutations can be } \\
\text { performed routinely in EBUS-IEUS-FNA samples }\end{array}$ \\
\hline Soh et $a^{50}$ & Cell-free PLE ( $n=61)$ & $\begin{array}{l}\text { Direct sequencing versus } \\
\text { mutant-enriched PCR versus } \\
\text { non-enriched PCR versus PNA-LNA } \\
\text { PCR-clamp }\end{array}$ & $\begin{array}{l}\text { Some discrepancies between the results of the four } \\
\text { assays were noted. Mutant-enriched PCR detected the } \\
\text { most mutations }\end{array}$ \\
\hline $\begin{array}{l}\text { Takano } \\
\text { et } a l^{23}\end{array}$ & $\begin{array}{l}\text { Bronchial brushing/washing }(n=43) \text {, PLE }(n=40) \text {, } \\
\text { transbronchial FNA }(n=9), P C E(n=8) \text {, superficial lymph } \\
\text { node FNA }(n=7) \text {, tumour FNA }(n=6) \text {, and sputum }(n=4)\end{array}$ & HRMA versus direct sequencing & $\begin{array}{l}\text { Exon } 19 \text { deletions and the exon } 21 \text { point mutation } \\
\text { L858R can likely be detected from archived } \\
\text { Papanicolaou-stained cytology slides with sensitivity of } \\
\text { ca. } 90 \% \text { and specificity of ca. } 100 \%\end{array}$ \\
\hline $\begin{array}{l}\text { van Eijk } \\
\text { et } a l^{56}\end{array}$ & $\begin{array}{l}\text { EBUS-TBNA/EUS-FNA samples (numerous samples from } \\
43 \text { patients) }\end{array}$ & Real-time PCR with hydrolysis probes & $\begin{array}{l}\text { All mutations detected in matched histological samples } \\
\text { were also identified in the cytology samples }\end{array}$ \\
\hline $\begin{array}{l}\text { Yasuda } \\
\text { et } a l^{70}\end{array}$ & $\operatorname{ELF}(n=23)$ & PNA-LNA PCR clamp & Sensitivity for detecting mutations in ELF was $58 \%$ \\
\hline Zhang et $a l^{71}$ & PLE cells and matched cell-free PLE $(n=26)$ & $\begin{array}{l}\text { Mutant-enriched PCR versus direct } \\
\text { sequencing }\end{array}$ & $\begin{array}{l}\text { Direct sequencing may miss a significant proportion of } \\
\text { mutations in PLE samples. Mutant-enriched PCR may } \\
\text { be more reliable }\end{array}$ \\
\hline Smits et al ${ }^{72}$ & $\begin{array}{l}\text { Cytology and FFPE samples ( } n=816 ; 719 \text { samples had } \\
\text { interpretable result) }\end{array}$ & Direct sequencing or HRMA & $\begin{array}{l}\text { (Results of cytology sample analyses were combined } \\
\text { with those of FFPE specimens) }\end{array}$ \\
\hline Tsai et al ${ }^{73}$ & PLE $(n=78)$ & IHC versus direct sequencing & $\begin{array}{l}\text { EGFR mutations were detected in PLE with } 71 \% \text { and } \\
88 \% \text { sensitivity using antibodies specific for the exon } \\
19 \text { deletion E746_A750 and the exon } 21 \text { point } \\
\text { mutation L858R, respectively }\end{array}$ \\
\hline
\end{tabular}


Table 3 Continued

\begin{tabular}{|c|c|c|c|}
\hline Reference & $\begin{array}{l}\text { Cytology samples (no. of samples for mutation } \\
\text { analysis (fail data if available)) }\end{array}$ & $\begin{array}{l}\text { Method(s) of EGFR mutation testing } \\
\text { assessed }\end{array}$ & $\begin{array}{l}\text { Authors' conclusions on use of cytology samples } \\
\text { for EGFR mutation testing }\end{array}$ \\
\hline & & & $\begin{array}{l}\text { Correlation of TKI response rate with EGFR mutation } \\
\text { status was comparable when determined by IHC and } \\
\text { direct sequencing ( } 67 \% \text { vs } 72 \%)\end{array}$ \\
\hline $\begin{array}{l}\text { Navani } \\
\text { et } a l^{57}\end{array}$ & EBUS-TBNA samples $(n=774)$ & ARMS or MassARRAY & $\begin{array}{l}\text { EBUS-TBNA cytology samples are suitable for EGFR } \\
\text { analysis }\end{array}$ \\
\hline Aisner et $\mathrm{al}^{74}$ & $\begin{array}{l}\text { Cytology cell blocks, including FNA of primary and } \\
\text { metastatic lung lesions and exfoliative cytology } \\
\text { specimens ( } n=42 \text { ) }\end{array}$ & PCR-sequencing & $\begin{array}{l}\text { Cell block specimens provide an alternative DNA source } \\
\text { to surgical specimens for EGFR analysis }\end{array}$ \\
\hline $\begin{array}{l}\text { Zhuang } \\
\text { et }\left.a\right|^{55}\end{array}$ & CT-guided FNA biopsy $(n=43)$ & Direct sequencing & $\begin{array}{l}\text { CT-guided FNA biopsy is a feasible and safe method to } \\
\text { provide samples for EGFR analysis }\end{array}$ \\
\hline Santis et $a^{58}$ & $\begin{array}{l}\text { EBUS-TBNA lymph node samples ( } n=131 \text {; successful } \\
\text { analysis of } 126 \text { samples) }\end{array}$ & COLD-PCR & $\begin{array}{l}\text { EBUS-TBNA samples provide sufficient tumour material } \\
\text { for } E G F R \text { mutation analysis } \\
\text { COLD-PCR is a robust screening assay for EGFR } \\
\text { mutations }\end{array}$ \\
\hline $\begin{array}{l}\text { Malapelle } \\
\text { et } a l^{75}\end{array}$ & $\mathrm{LBC}(\mathrm{n}=42)$ & Direct sequencing & $\begin{array}{l}\text { LBC samples can be used for EGFR mutation analysis; } \\
\text { however, direct sequencing requires micro-dissection to } \\
\text { provide sufficient sample DNA }\end{array}$ \\
\hline Betz et $a l^{76}$ & Romanowsky-stained direct cytology smears $(n=33)$ & Direct sequencing & $\begin{array}{l}\text { Following micro-dissection, direct smears can be used } \\
\text { as a specimen source for } E G F R \text { analysis when cell } \\
\text { blocks exhibit insufficient cellularity }\end{array}$ \\
\hline Cho et $a l^{77}$ & $\begin{array}{l}\text { Body fluid specimen }(n=32 \text { : pleural fluids }(n=29) \text {, CSF } \\
(n=1) \text {, pericardial }(n=1) \text {, and ascites }(n=1))\end{array}$ & Direct sequencing & $\begin{array}{l}\text { Combined direct sequencing and cytological analysis } \\
\text { might be clinically useful and sensitive for the } \\
\text { detection of EGFR mutations }\end{array}$ \\
\hline Tsai et $\left.a\right|^{52}$ & PLE $(n=150)$ & $\begin{array}{l}\text { Direct sequencing of cell-derived RNA } \\
\text { versus genomic DNA }\end{array}$ & $\begin{array}{l}\text { Sequencing of RNA improves sensitivity for EGFR } \\
\text { mutation detection in PLE samples compared with } \\
\text { genomic DNA }\end{array}$ \\
\hline $\begin{array}{l}\text { Lozano } \\
\text { et a }\left.\right|^{66}\end{array}$ & $\begin{array}{l}\text { Cytology samples ( } n=150 \text { : Papanicolaou smears } \\
(n=120) \text {, Fresh/liquid }(n=14) \text {, cell block }(n=10) \text {, } \\
\text { ThinPrep tests }(n=6))\end{array}$ & Direct sequencing & $\begin{array}{l}\text { EGFR analysis using cytological samples is feasible and } \\
\text { comparable with biopsy results }\end{array}$ \\
\hline $\begin{array}{l}\text { Nakajima } \\
\text { et } a^{59}\end{array}$ & EBUS-TBNA metastatic lymph node samples $(n=156)$ & PNA-LNA PCR clamp & $\begin{array}{l}\text { EBUS-TBNA samples can be used for multi-gene } \\
\text { mutational analysis }\end{array}$ \\
\hline
\end{tabular}

ensure that mutations are properly identified. ${ }^{24}$ This can be problematic when levels of mutant DNA do not permit analysis by direct sequencing.

Targeted methods, which detect specific mutations only, tend to be more sensitive in terms of limit of detection than screening techniques. ARMS, for example, is a simple PCR-based testing method shown to be more sensitive and robust than direct sequencing for the assessment of common EGFR mutations in FFPE tumour tissue. ${ }^{31}$ One other targeted method to be validated is fragment length analysis. While fragment length analysis is used widely in practice, it can only detect insertions or deletions and does not allow detection of point mutations in EGFR. Compared with some other methods, mutant-specific IHC is fast, cost-effective, and can be performed in most

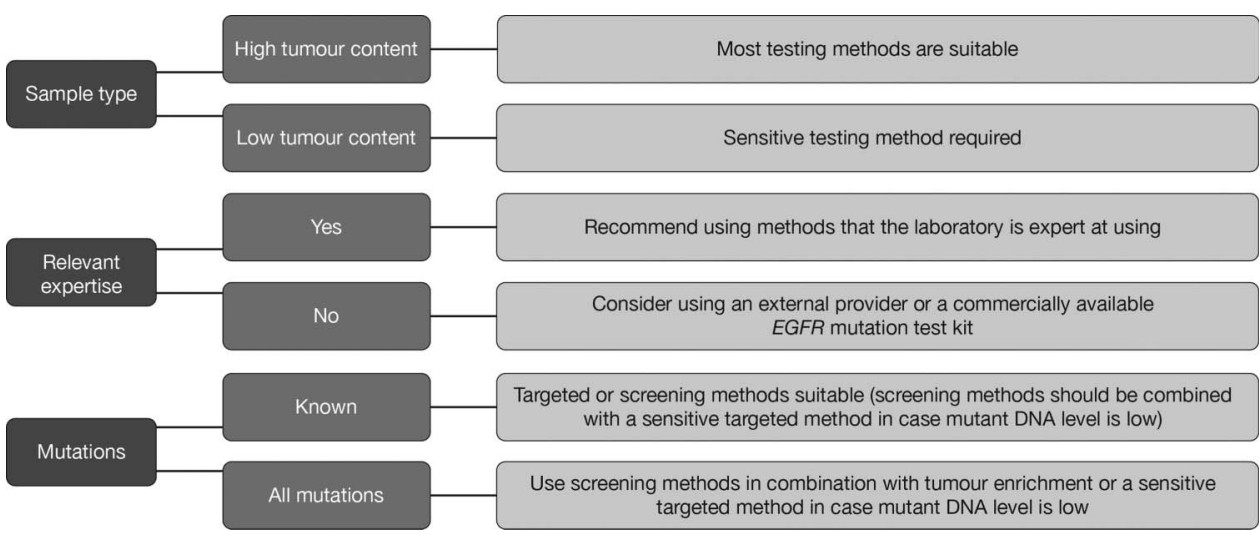

Figure 1 Factors determining the choice of EGFR mutation testing method. 
pathology laboratories. ${ }^{44}$ IHC, however, has not been widely adopted for EGFR mutation analysis amid concerns that it is not as sensitive or as specific as DNA-based molecular techniques. A study comparing EGFR mutation testing between 15 centres in France (the Evaluation of the EGFR Mutation Status for the Administration of EGFR-TKIs in Non-Small Cell Lung Carcinoma (ERMETIC) project) suggested that detection accuracy is dependent upon sample quality rather than the sequencing method used, highlighting the importance of good sample collection and processing techniques. ${ }^{83}$ For poor quality samples, care must be taken to ensure the selection of tumour cells, in addition to the DNA concentration, as test results are frequently dependent on both these parameters.

The availability of targeted methods with high sensitivity offers the potential for accurate, rapid, and high-throughput analysis of clinical samples. The main theoretical drawback of these techniques is their inability to detect all activating EGFR mutations. The majority of clinical evidence to date robustly supports the use of EGFR TKIs in patients with the two most common activating mutations in EGFR (exon 19 deletions and the L858R point mutation in exon 21), and most targeted methods are specifically designed to detect these mutations. However, clinical data on less common mutations are emerging and further research is required to fully inform predictable outcomes on EGFR TKIs, aided by the use of sample micro dissection followed by screening methods, to ensure identification of all known mutations. ${ }^{18}$ While targeted methods can fail to detect some of the rare mutations which are detected by screening, it is anticipated that rare mutations demonstrated to have therapeutic implications will subsequently be included in targeted screening approaches, thus ensuring all patients will benefit from the appropriate therapy. Both screening and targeted methods have been used to identify EGFR mutations in clinical trials of EGFR TKIs in patients with advanced NSCLC. ${ }^{6-10}$ 14-16 84 These trials were not identified by our search due to our focus on method comparison studies. In practice, laboratories can opt to use commercially available kits or to develop their own tests. Testing kits such as those utilising the ARMS method have the advantages of being validated, ready for use and quality controlled. Laboratory-developed tests, many of which were identified by our search, may be less expensive, but take time to develop and validate and may have limited quality control. If procedures for EGFR mutation testing are not established at a local level, use of one of a number of global testing laboratories may be considered. Such laboratories use a variety of methods for EGFR mutation testing including commercially available kits and laboratory-developed tests.

Our literature search confirmed that cytology samples are suitable testing material for EGFR mutation testing and that detection rates appear to be as high as those obtained with traditional tissue samples. The suitability of cytology samples for routine clinical practice has been recognised in published recommendations for EGFR mutation testing. ${ }^{85}$ Of note, in the recent study of Goto and colleagues, published after we performed our literature search, five different EGFR testing methods (PCR-Invader, PNA-LNA-PCR clamp, PCR-direct sequencing, cycleave PCR, and ARMS) showed comparable performance in the assessment of tissue and cytology samples. Furthermore, the concordance between matched tumour and cytology samples was extremely high. ${ }^{86}$

There is a growing trend toward the extensive molecular characterisation of tumours so that the most appropriate therapy can be selected. This is exemplified in the Biomarker-integrated Approaches of Targeted Therapy for Lung cancer Elimination trial, in which patients are adaptively randomised to various treatments based on relevant molecular biomarkers. ${ }^{87}$ This approach has been made possible by the availability of methods such as Sequenom MassArray, ${ }^{88}$ SNaPshot, ${ }^{89-91}$ and arrays of mutation-specific PCR assays (eg, qBiomarker Somatic Mutation PCR Array), and through the use of next-generation sequencing. These methods can rapidly and sensitively detect many known mutations in a relatively small amount of DNA. Using such gene panel approaches will no doubt increase our knowledge of pharmacogenetic predictive biomarkers and therefore improve patient outcomes by ensuring that each patient is given a treatment with the most likely chance of success. To date, no point-of-care devices are available for EGFR mutation testing; the future development of such devices would be welcome and would help ensure that treatment is not delayed while test results are awaited.

\section{CONCLUSIONS}

The EGFR mutation testing landscape is varied and includes a number of screening and targeted methods. Each method has its own benefits and limitations and the choice of method used in practice should be made according to the nature of the sample to be tested, the testing laboratory's expertise and access to equipment, and whether detection of known activating EGFR mutations only or all possible mutations is required. Cytology samples can be used to reliably detect EGFR mutations. Mutation detection rates with cytology samples are comparable with those achieved with traditional tissue samples obtained by biopsy or resection.

\section{Key messages}

- The development of targeted EGFR mutation testing methods and commercially available test kits has enabled sensitive, rapid and robust analysis of clinical samples from patients with NSCLC.

- The use of screening methods, either used alone or in conjunction with targeted methods, enables the detection of more rare and novel EGFR mutations.

- Evidence published to date suggests cytology samples (including fine needle aspirate and pleural effusion) are viable alternatives for mutation testing when tumour tissue samples are not available.

- The choice of method used in practice should be made according to the nature of the sample to be tested, the testing laboratory's expertise and access to equipment, and whether detection of known activating EGFR mutations only or all possible mutations is required.

Acknowledgements Medical writing support was provided by Rick Flemming, PhD, CMPP and Annette Smith, PhD of Complete Medical Communications, and was funded by AstraZeneca.

Contributors All authors made substantial contributions to the conception, design and execution of the review and interpretation of the data. All authors contributed to the intellectual content of the manuscript, reviewed and critically revised it and approved of the final submitted version.

Funding This study, including design, collection/analysis/interpretation of data, writing, and decision to submit this manuscript for publication was supported by AstraZeneca.

Competing interests $G E, G Z, A M, S D, G S$, and RM are full-time employees of AstraZeneca. GE, SD, GS, and RM are holders of AstraZeneca shares.

Provenance and peer review Not commissioned; externally peer reviewed. 
Open Access This is an Open Access article distributed in accordance with the Creative Commons Attribution Non Commercial (CC BY-NC 3.0) license, which permits others to distribute, remix, adapt, build upon this work non-commercially, and license their derivative works on different terms, provided the original work is properly cited and the use is non-commercial. See: http://creativecommons.org/ licenses/by-nc/3.0/

\section{REFERENCES}

1 Ferlay J, Shin HR, Bray F, et al. Estimates of worldwide burden of cancer in 2008 : GLOBOCAN 2008. Int I Cancer 2010;127:2893-917.

2 Azzoli CG, Baker S Jr, Temin S, et al. American Society of Clinical Oncology Clinical Practice Guideline update on chemotherapy for stage IV non-small-cell lung cancer. J Clin Oncol 2009:27:6251-66.

3 Lynch TJ, Bell DW, Sordella R, et al. Activating mutations in the epidermal growth factor receptor underlying responsiveness of non-small-cell lung cancer to gefitinib. N Engl J Med 2004;350:2129-39.

4 Paez JG, Jänne PA, Lee JC, et al. EGFR mutations in lung cancer: correlation with clinical response to gefitinib therapy. Science 2004;304:1497-500.

5 Pao W, Miller V, Zakowski M, et al. EGF receptor gene mutations are common in lung cancers from "never smokers" and are associated with sensitivity of tumors to gefitinib and erlotinib. Proc Natl Acad Sci USA 2004;101:13306-11.

6 Maemondo M, Inoue A, Kobayashi K, et al. Gefitinib or chemotherapy for non-small-cell lung cancer with mutated EGFR. N Engl J Med 2010;362:2380-8.

7 Mitsudomi T, Morita S, Yatabe Y, et al. Gefitinib versus cisplatin plus docetaxel in patients with non-small-cell lung cancer harbouring mutations of the epidermal growth factor receptor (WJTOG3405): an open label, randomised phase 3 trial. Lancet Oncol 2010;11:121-8.

8 Mok TS, Wu Y-L, Thongprasert S, et al. Gefitinib or carboplatin-paclitaxel in pulmonary adenocarcinoma. N Engl J Med 2009;361:947-57.

9 Rosell R, Carcereny E, Gervais R, et al. Erlotinib versus standard chemotherapy as first-line treatment for European patients with advanced EGFR mutation-positive non-small-cell lung cancer (EURTAC): a multicentre, open-label, randomised phase 3 trial. Lancet Oncol 2012:13:239-46.

10 Zhou C, Wu Y-L, Chen G, et al. Erlotinib versus chemotherapy as first-line treatment for patients with advanced EGFR mutation-positive non-small-cell lung cancer (OPTIMAL, CTONG-0802): a multicentre, open-label, randomised, phase 3 study. Lancet Oncol 2011:12:735-42.

11 Han JY, Park K, Kim SW, et al. First-SIGNAL: First-Line Single-Agent Iressa Versus Gemcitabine and Cisplatin Trial in never-smokers with adenocarcinoma of the lung. J Clin Oncol 2012;30:1122-8.

12 Keedy VL, Temin S, Somerfield MR, et al. American Society of Clinical Oncology Provisional Clinical Opinion: epidermal growth factor receptor (EGFR) mutation testing for patients with advanced non-small-cell lung cancer considering first-line EGFR tyrosine kinase inhibitor therapy. J Clin Oncol 2011:29:2121-7.

13 Sharma SV, Bell DW, Settleman J, et al. Epidermal growth factor receptor mutations in lung cancer. Nat Rev Cancer 2007;7:169-81.

14 Cortes-Funes H, Gomez C, Rosell R, et al. Epidermal growth factor receptor activating mutations in Spanish gefitinib-treated non-small-cell lung cancer patients, Ann Oncol 2005;16:1081-6.

15 Tokumo M, Toyooka S, Kiura K, et al. The relationship between epidermal growth factor receptor mutations and clinicopathologic features in non-small cell lung cancers. Clin Cancer Res 2005:11:1167-73.

16 Yoshida K, Yatabe Y, Park JY, et al. Prospective validation for prediction of gefitinib sensitivity by epidermal growth factor receptor gene mutation in patients with non-small cell lung cancer. J Thorac Oncol 2007;2:22-8.

17 Eberhard DA, Giaccone G, Johnson BE. Biomarkers of response to epidermal growth factor receptor inhibitors in non-small-cell lung cancer working group: standardization for use in the clinical trial setting. J Clin Oncol 2008;26:983-94.

18 Penzel R, Sers C, Chen Y, et al. EGFR mutation detection in NSCLC - assessment of diagnostic application and recommendations of the German Panel for Mutation Testing in NSCLC. Virchows Arch 2011:458:95-8.

19 da Cunha Santos G, Saieg MA, Geddie W, et al. EGFR gene status in cytological samples of nonsmall cell lung carcinoma: controversies and opportunities. Cancer Cytopathol 2011;119:80-91.

20 Sueoka N, Sato A, Eguchi $H$, et al. Mutation profile of EGFR gene detected by denaturing high-performance liquid chromatography in Japanese lung cancer patients. J Cancer Res Clin Oncol 2007;133:93-102.

21 Jänne $P A$, Borras $A M$, Kuang $Y$, et al. A rapid and sensitive enzymatic method for epidermal growth factor receptor mutation screening. Clin Cancer Res 2006:12:751-8.

22 Do H, Krypuy M, Mitchell PL, et al. High resolution melting analysis for rapid and sensitive EGFR and KRAS mutation detection in formalin fixed paraffin embedded biopsies. BMC Cancer 2008:8:142.

23 Takano T, Ohe Y, Tsuta $\mathrm{K}$, et al. Epidermal growth factor receptor mutation detection using high-resolution melting analysis predicts outcomes in patients with advanced non-small cell lung cancer treated with gefitinib. Clin Cancer Res 2007:13:5385-90.
24 Borràs $\mathrm{E}$, Jurado I, Hernan I, et al. Clinical pharmacogenomic testing of KRAS, $B R A F$ and EGFR mutations by high resolution melting analysis and ultra-deep pyrosequencing. BMC Cancer 2011;11:406.

25 Querings $\mathrm{S}$, Altmüller J, Ansén $\mathrm{S}$, et al. Benchmarking of mutation diagnostics in clinical lung cancer specimens. PLoS One 2011:6:e19601.

26 Endo K, Konishi A, Sasaki H, et al. Epidermal growth factor receptor gene mutation in non-small cell lung cancer using highly sensitive and fast TaqMan PCR assay. Lung Cancer 2005;50:375-84.

27 Yatabe $Y$, Hida T, Horio $Y$, et al. A rapid, sensitive assay to detect EGFR mutation in small biopsy specimens from lung cancer. J Mol Diagn 2006;8:335-41.

28 Ohnishi $\mathrm{H}$, Ohtsuka $\mathrm{K}$, Ooide $\mathrm{A}$, et al. A simple and sensitive method for detecting major mutations within the tyrosine kinase domain of the epidermal growth factor receptor gene in non-small-cell lung carcinoma. Diagn Mol Pathol 2006;15:101-8.

29 Asano H, Toyooka S, Tokumo M, et al. Detection of EGFR gene mutation in lung cancer by mutant-enriched polymerase chain reaction assay. Clin Cancer Res 2006:12:43-8.

30 Otani $\mathrm{H}$, Toyooka S, Soh J, et al. Detection of EGFR gene mutations using the wash fluid of CT-guided biopsy needle in NSCLC patients. J Thorac Oncol 2008;3:472-6.

31 Ellison $\mathrm{G}$, Donald $\mathrm{E}$, McWalter $\mathrm{G}$, et al. A comparison of ARMS and DNA sequencing for mutation analysis in clinical biopsy samples. J Exp Clin Cancer Res 2010;29:132.

32 Zhao J, Zhao J, Huang J, et al. A novel method for detection of mutation in epidermal growth factor receptor. Lung Cancer 2011;74:226-32.

33 Naoki K, Soejima K, Okamoto H, et al. The PCR-invader method (structure-specific $5^{\prime}$ nuclease-based method), a sensitive method for detecting EGFR gene mutations in lung cancer specimens; comparison with direct sequencing. Int I Clin Oncol 2011;16:335-44.

34 Kawada I, Soejima $\mathrm{K}$, Watanabe $\mathrm{H}$, et al. An alternative method for screening EGFR mutation using RFLP in non-small cell lung cancer patients. J Thorac Oncol 2008:3:1096-103.

35 Molina-Vila MA, Bertran-Alamillo J, Reguart N, et al. A sensitive method for detecting EGFR mutations in non-small cell lung cancer samples with few tumor cells. J Thorac Oncol 2008;3:1224-35.

36 Pan Q, Pao W, Ladanyi M. Rapid polymerase chain reaction-based detection of epidermal growth factor receptor gene mutations in lung adenocarcinomas. J Mol Diagn 2005;7:396-403.

37 Ikeda S, Takabe K, Inagaki M, et al. Detection of gene point mutation in paraffin sections using in situ loop-mediated isothermal amplification. Pathol Int 2007:57:594-9.

38 Dufort S, Richard MJ, Lantuejoul S, et al. Pyrosequencing, a method approved to detect the two major EGFR mutations for anti EGFR therapy in NSCLC. J Exp Clin Cancer Res 2011;30:57.

39 Han HS, Lim SN, An JY, et al. Detection of EGFR mutation status in lung adenocarcinoma specimens with different proportions of tumor cells using two methods of differential sensitivity. J Thorac Oncol 2012:7:355-64.

40 Yang Q, Qiu T, Wu W, et al. Simple and sensitive method for detecting point mutations of epidermal growth factor receptor using cationic conjugated polymers. ACS Appl Mater Interfaces 2011;3:4539-45.

41 Hoshi K, Takakura H, Mitani Y, et al. Rapid detection of epidermal growth factor receptor mutations in lung cancer by the SMart-Amplification Process. Clin Cancer Res 2007;13:4974-83

42 Miyamae Y, Shimizu K, Mitani Y, et al. Mutation detection of epidermal growth factor receptor and KRAS genes using the Smart Amplification Process version 2 from formalin-fixed, paraffin-embedded lung cancer tissue. J Mol Diagn 2010;12:257-64

43 Araki T, Shimizu K, Nakamura T, et al. Clinical screening assay for EGFR exon 19 mutations using PNA-clamp smart amplification process version 2 in lung adenocarcinoma. Oncol Rep 2011;26:1213-19.

44 Kozu Y, Tsuta K, Kohno T, et al. The usefulness of mutation-specific antibodies in detecting epidermal growth factor receptor mutations and in predicting response to tyrosine kinase inhibitor therapy in lung adenocarcinoma. Lung Cancer 2011;73:45-50

45 Brevet $\mathrm{M}$, Arcila $\mathrm{M}$, Ladanyi $\mathrm{M}$. Assessment of EGFR mutation status in lung adenocarcinoma by immunohistochemistry using antibodies specific to the two major forms of mutant EGFR. J Mol Diagn 2010:12:169-76.

46 Ilie MI, Hofman V, Bonnetaud C, et al. Usefulness of tissue microarrays for assessment of protein expression, gene copy number and mutational status of EGFR in lung adenocarcinoma. Virchows Arch 2010;457:483-95.

47 Kato Y, Peled N, Wynes MW, et al. Novel epidermal growth factor receptor mutation-specific antibodies for non-small cell lung cancer: immunohistochemistry as a possible screening method for epidermal growth factor receptor mutations. J Thorac Oncol 2010:5:1551-8.

48 Nakamura H, Mochizuki A, Shinmyo T, et al. Immunohistochemical detection of mutated epidermal growth factor receptors in pulmonary adenocarcinoma. Anticancer Res 2010;30:5233-7.

49 Simonetti $S$, Molina MA, Queralt $C$, et al. Detection of EGFR mutations with mutation-specific antibodies in stage IV non-small-cell lung cancer. J Trans/ Med 2010:8:135. 
50 Soh J, Toyooka S, Aoe K, et al. Usefulness of EGFR mutation screening in pleural fluid to predict the clinical outcome of gefitinib treated patients with lung cancer. Int J Cancer 2006;119:2353-8.

51 Kimura H, Fujiwara Y, Sone T, et al. High sensitivity detection of epidermal growth factor receptor mutations in the pleural effusion of non-small cell lung cancer patients. Cancer Sci 2006;97:642-8.

52 Tsai T-H, Su K-Y, Wu S-G, et al. RNA is favourable for analysing EGFR mutations in malignant pleural effusion of lung cancer. Eur Respir J 2012;39:677-84.

53 Horiike A, Kimura H, Nishio K, et al. Detection of epidermal growth factor receptor mutation in transbronchial needle aspirates of non-small cell lung cancer. Chest 2007;131:1628-34.

54 Schuurbiers OCJ, Looijen-Salamon MG, Ligtenberg MJL, et al. A brief retrospective report on the feasibility of epidermal growth factor receptor and KRAS mutation analysis in transesophageal ultrasound- and endobronchial ultrasound-guided fine needle cytological aspirates. J Thorac Oncol 2010;5:1664-7.

55 Zhuang $\mathrm{Y}-\mathrm{P}$, Wang $\mathrm{H}-\mathrm{Y}$, Shi $\mathrm{M}-\mathrm{Q}$, et al. Use of CT-guided fine needle aspiration biopsy in epidermal growth factor receptor mutation analysis in patients with advanced lung cancer. Acta Radiol 2011;52:1083-7.

56 van Eijk R, Licht J, Schrumpf M, et al. Rapid KRAS, EGFR, BRAF and PIK3CA mutation analysis of fine needle aspirates from non-small-cell lung cancer using allele-specific qPCR. PLoS One 2011;6:e17791.

57 Navani N, Brown JM, Nankivell M, et al. Suitability of EBUS-TBNA specimens for subtyping and genotyping of NSCLC: a multi-centre study of 774 patients. Am J Respir Crit Care Med 2012;185:1316-22.

58 Santis $G$, Angell $R$, Nickless $G$, et al. Screening for EGFR and KRAS mutations in endobronchial ultrasound derived transbronchial needle aspirates in non-small cell lung cancer using COLD-PCR. PLoS One 2011;6:e25191.

59 Nakajima T, Yasufuku K, Nakagawara A, et al. Multigene mutation analysis of metastatic lymph nodes in non-small cell lung cancer diagnosed by endobronchial ultrasound-guided transbronchial needle aspiration. Chest 2011;140:1319-24.

60 Nakajima T, Yasufuku K, Suzuki M, et al. Assessment of epidermal growth factor receptor mutation by endobronchial ultrasound-guided transbronchial needle aspiration. Chest 2007;132:597-602.

61 Fassina A, Gazziero A, Zardo D, et al. Detection of EGFR and KRAS mutations on trans-thoracic needle aspiration of lung nodules by high resolution melting analysis. J Clin Pathol 2009:62:1096-102.

62 Hlinkova K, Babál P, Berzinec P, et al. Rapid and efficient detection of EGFR mutations in problematic cytologic specimens by high-resolution melting analysis. Mol Diagn Ther 2011;15:21-9.

63 Kawahara A, Azuma K, Sumi A, et al. Identification of non-small-cell lung cancer with activating EGFR mutations in malignant effusion and cerebrospinal fluid: rapid and sensitive detection of exon 19 deletion E746-A750 and exon 21 L858R mutation by immunocytochemistry. Lung Cancer 2011;74:35-40.

64 Kimura $\mathrm{H}$, Fujiwara $Y$, Sone $T$, et al. EGFR mutation status in tumour-derived DNA from pleural effusion fluid is a practical basis for predicting the response to gefitinib. Br J Cancer 2006;95:1390-5.

65 Lim EH, Zhang S-L, Li J-L, et al. Using whole genome amplification (WGA) of low-volume biopsies to assess the prognostic role of EGFR, KRAS, p53, and CMET mutations in advanced-stage non-small cell lung cancer (NSCLC). J Thorac Oncol 2009:4:12-21.

66 Lozano MD, Zulueta JJ, Echeveste Jl, et al. Assessment of epidermal growth factor receptor and k-ras mutation status in cytological stained smears of non-small cell lung cancer patients: correlation with clinical outcomes. Oncologist 2011;16:877-85.

67 Oshita F, Matsukuma S, Yoshihara M, et al. Novel heteroduplex method using small cytology specimens with a remarkably high success rate for analysing EGFR gene mutations with a significant correlation to gefitinib efficacy in non-small-cell lung cancer. Br J Cancer 2006;95:1070-5.

68 Rekhtman N, Brandt SM, Sigel CS, et al. Suitability of thoracic cytology for new therapeutic paradigms in non-small cell lung carcinoma: high accuracy of tumor subtyping and feasibility of EGFR and KRAS molecular testing. J Thorac Oncol 2011:6:451-8.

69 Savic S, Tapia C, Grilli B, et al. Comprehensive epidermal growth factor receptor gene analysis from cytological specimens of non-small-cell lung cancers. $\mathrm{Br} J$ Cancer 2008;98:154-60.
70 Yasuda H, Soejima K, Nakayama S, et al. Bronchoscopic microsampling is a useful complementary diagnostic tool for detecting lung cancer. Lung Cancer 2011;72:32-8.

71 Zhang $X$, Zhao $Y$, Wang $M$, et al. Detection and comparison of epidermal growth factor receptor mutations in cells and fluid of malignant pleural effusion in non-small cell lung cancer. Lung Cancer 2008;60:175-82.

72 Smits AJ, Kummer JA, Hinrichs JW, et al. EGFR and KRAS mutations in lung carcinomas in the Dutch population: increased EGFR mutation frequency in malignant pleural effusion of lung adenocarcinoma. Cell Oncol (Dordr) 2012;35:189-96.

73 Tsai T-H, Wu S-G, Chang Y-L, et al. Effusion immunocytochemistry as an alternative approach for the selection of first-line targeted therapy in advanced lung adenocarcinoma. J Thorac Oncol 2012;7:993-1000.

74 Aisner DL, Deshpande C, Baloch Z, et al. Evaluation of EGFR mutation status in cytology specimens: an institutional experience. Diagn Cytopathol 2011;doi: 10.1002/dc. 21851.

75 Malapelle $U$, de Rosa N, Rocco D, et al. EGFR and KRAS mutations detection on lung cancer liquid-based cytology: a pilot study. J Clin Pathol 2012;65:87-91.

76 Betz BL, Roh MH, Weigelin HC, et al. The application of molecular diagnostic studies interrogating EGFR and KRAS mutations to stained cytologic smears of lung carcinoma. Am J Clin Pathol 2011;136:564-71.

77 Cho MC, Choi CM, Kim S, et al. Direct sequencing in cytological specimens as a useful strategy for detecting EGFR mutations in non-small cell lung cancer patients. Clin Chem Lab Med 2011;50:565-72.

78 Li J, Wang L, Mamon H, et al. Replacing PCR with COLD-PCR enriches variant DNA sequences and redefines the sensitivity of genetic testing. Nat Med 2008; 14:579-84

79 Ogino S, Kawasaki T, Brahmandam M, et al. Sensitive sequencing method for KRAS mutation detection by Pyrosequencing. J Mol Diagn 2005;7:413-21.

80 Coghlin CL, Smith LJ, Bakar S, et al. Quantitative analysis of tumor in bronchial biopsy specimens. J Thorac Oncol 2010;5:448-52.

81 Chowdhuri SR, Xi L, Pham TH, et al. EGFR and KRAS mutation analysis in cytologic samples of lung adenocarcinoma enabled by laser capture microdissection. Mod Pathol 2012;25:548-55.

82 Whitehall V, Tran K, Umapathy A, et al. A multicenter blinded study to evaluate KRAS mutation testing methodologies in the clinical setting. J Mol Diagn 2009;11:543-52

83 Beau-Faller M, Degeorges A, Rolland E, et al. Cross-validation study for epidermal growth factor receptor and KRAS mutation detection in 74 blinded non-small cell lung carcinoma samples: a total of 5550 exons sequenced by 15 molecular French laboratories (evaluation of the EGFR mutation status for the administration of EGFRTKIs in non-small cell lung carcinoma [ERMETIC] project-part 1). J Thorac Oncol 2011;6:1006-15.

84 Rosell $R$, Ichinose $Y$, Taron $M$, et al. Mutations in the tyrosine kinase domain of the EGFR gene associated with gefitinib response in non-small-cell lung cancer. Lung Cancer 2005:50:25-33.

85 Marchetti A, Normanno N, AIOM-SIAPEC-IAP, et al. Recommendation for mutational analysis of EGFR in lung carcinoma. Pathologica 2010; 102:119-22.

86 Goto K, Satouchi M, Ishii G, et al. An evaluation study of EGFR mutation tests utilized for non-small-cell lung cancer in the diagnostic setting. Ann Oncol 2012; 2012;23:2914-9

87 Kim ES. The BATTLE trial: personalizing therapy for lung cancer. Cancer Discov 2011;1:43-51.

88 MacConaill LE, Campbell CD, Kehoe SM, et al. Profiling critical cancer gene mutations in clinical tumor samples. PLoS One 2009;4:e7887.

89 Dias-Santagata D, Akhavanfard S, David SS, et al. Rapid targeted mutational analysis of human tumours: a clinical platform to guide personalized cancer medicine. EMBO Mol Med 2010;2:146-58.

90 Su Z, Dias-Santagata D, Duke M, et al. A platform for rapid detection of multiple oncogenic mutations with relevance to targeted therapy in non-small-cell lung cancer. J Mol Diagn 2011;13:74-84.

91 Sequist LV, Heist RS, Shaw AT, et al. Implementing multiplexed genotyping of non-small-cell lung cancers into routine clinical practice. Ann Oncol 2011;22:2616-24. 